\title{
Legitimacy, social capital, and dirty hands: a three-constituent approach to ethics and leadership under duress
}

\author{
Paul Sanders \\ NEOMA Business School, Reims Campus, Department of Economics, Culture and International Affairs, \\ France
}

This article problematizes leadership ethics in the context of a duress situation, using the concept of dirty hands. Comparative historical case study material from the German Occupation of the British Crown Dependencies of Guernsey and Jersey in the Second World War showcases how dealing with the incumbent leadership challenges posed by duress can be ethically optimized. The article argues that this is related to the management of social capital and legitimacy. The article's relevance to global leadership is owed to the fact that globalization increases gray zones and, with it, the likelihood of dirty hands reflexes. It contributes to an ongoing historical turn in management studies, through its advocacy of the historical method.

Keywords: legitimacy, dirty hands, social capital, leadership ethics, wicked problems, extreme contexts, German occupation of the British Channel Islands 1940-1945

\section{INTRODUCTION ${ }^{1}$}

In an article published in 2010 that investigated civilian leadership responses to an extreme context (Hannah et al. 2009), the German Occupation of the British Channel Islands in the Second World War, I showcased the social capital dimension of ethics and leadership under duress (Sanders 2010). My aim was to comparatively measure ethical leadership outcomes in the two main islands of Jersey and Guernsey and explain the difference through the social capital link. The key limitation of the approach was that it did not describe the exact mechanism, something I will attempt to do in the pages that follow. For this, I will integrate several additional notions into the black box of ethical duress leadership: dirty hands, so-called wicked problems and legitimacy. The article will argue that instead of laying one's trust in normative and prescriptive frameworks, the correct discursive nexus for the solution of complex leadership problems with a clear ethical dimension is the triangle of social capital, legitimacy, and dirty hands. In line with Hannah et al. (2009, p. 898), who state that leadership can 'intensify or attenuate levels of extremity,' I argue that social capital and legitimacy are the two constituents of the duress leader's toolbox that can temper dirty hands; as well as minimize the level of dirty hands necessary to attain outcomes that are consistent with ethics.

1. Key to footnotes in this paper: IA = Island Archives, Guernsey; IWM = Imperial War Museum, London; JAS = Jersey Archives Service, Jersey; TNA = The National Archives, London. 
Leadership under duress as defined here corresponds to leadership in extreme contexts, a concept coined by Hannah et al. (2009). Rather than mere crisis, this topos relates to a particularly 'extensive and intolerable magnitude of physical, psychological, or material' threat to an organization (ibid., p. 898). It is 'one of the least researched areas in the leadership field', but, at the same time, 'perhaps the area where leadership is most needed' (ibid., pp. 897 and 898). The term duress was chosen because it encapsulates particularly well the entrapment of entities and individuals alike in an unjust system, and the double binds and dilemmas this entails.

The notion of dirty hands emerged in response to the inadequacies of conventional virtue, justice, and rights approaches to provide a reliable framework for moral action in duress situations, characterized as they are by high levels of competition, outright war, or war-like conditions. Dirty hands circumscribes what one might call legitimate ruthlessness. Typically, it does not attach to the metaphysics of manifest or absolute evil, but to those good men who find themselves under an obligation to commit transgressions that they themselves would deem unethical in other contexts, such as their private lives. It caters to the fact that duress does not allow the luxury of straightforward solutions devoid of moral ambiguity, but requires the identification of a lesser evil. Dirty hands shares one feature with common dilemmas, namely that all existing options for action are unpalatable. However, unlike dilemmas, where no direction exists as to which action should be taken, in dirty hands situations the necessary choice of option is painful, but obvious (Coady 2011).

As a term, dirty hands appears for the first time as the title of a play by French existentialist philosopher Jean-Paul Sartre, which premiered in 1948, but its origins are much older. It is preconfigured in Plato's noble lies, and it provides the bedrock for Machiavelli's take on a utilitarian doing good by doing evil. The beginnings of a structured dirty hands discussion stretch back to the politicized context of the Vietnam War and in particular the work of Michael Walzer. After some decades off the radar, the notion was reactivated in the wake of 9/11, when it informed the debate on the curtailment of rights, the war on terror, torture lite, and ticking bomb scenarios (indicatively Ignatieff 2004).

It is important to stress that dirty hands does not amount to a blank check for immoral behavior. As Stephen Garrett (1993, p. 22) writes about reliance on dirty hands, 'there are certain circumstances in which this may be morally justifiable, whereas there are other situations in which a moral defense is much more problematical.' Machiavelli's 'the ends justify the means' comes attached with a fundamental proviso: the ends must bear a relation to superior moral goods. This is what emerges from a reading of his The Discourses on the First Decade of Titus Livius (Machiavelli 1965). Another thing that emerges is the conditions to which arguing a true Machiavellian case attaches. Sometimes criticized as teacher of evil, Machiavelli's real leanings are republican and libertarian. As a Renaissance scholar, his definition of superior moral goods is squarely based on his admiration for the Ancient Roman Republic. No efforts, for example, should be spared to safeguard a strong republic that respects individual liberty and guarantees the well-being of its inhabitants (Harris 2001, pp. 1139-1140). This means that not all ends, nor even most ends, justify the means (Alexandra 2007, p. 2). Viciousness is always a last resort, permissible once all other options have been exhausted. ${ }^{2}$

2. The central tenet, that the wise prince does good if he can, but should be prepared to act in the opposite way if he must, is outlined in chapter XVIII of The Prince. 


\section{COLLABORATION AND RESISTANCE AS A DIRTY HANDS PROBLEM}

The Second World War provides a particularly dramatic backdrop for the issues and ambiguities involved, as it is generally perceived as the epitome of a just war, a pitched battle between the forces of good and evil. Exemplary in this respect is the work of Walzer, Garrett, and John Rawls, all of whom wrote on dirty hands by drawing on Second World War case studies (Walzer 1977; 2004, pp. 33-50; Garrett 1993; 1996; Rawls 1999). Their pivotal focus was the most heavily debated Allied wrong of the war, the firebombing of German and Japanese civilians, and the deployment of atomic weapons in August 1945.

Before turning to the case under consideration, a brief geographical and historical survey is necessary. The British Channel Islands are micro-states, situated in the bay of Saint-Malo, in close geographical proximity to France. As crown dependencies, Whitehall and Westminster have no jurisdiction in the islands, which are completely independent from the UK constitutional and political process. Each bailiwick has its own parliament, government, legal system, and administration, and each is headed by a Bailiff, a role combining executive, legislative, and judiciary powers, and answerable to the Crown only. Merely the areas of defense, citizenship, and foreign affairs are outsourced to the UK government. As a result of these particularities, the islands are not interlinked constitutionally or institutionally. Their only commonality is the geographical denomination (Channel Islands) and their shared Norman French culture. Prior to the Occupation in 1940, both islands had taken steps to streamline their decentralized executive to allow for swift decision-making, through the creation of a Superior Council (Jersey) and a Controlling Committee (Guernsey). About one-fourth of the population evacuated to Britain, in mid-June 1940. German forces landed in the islands on June 30, 1940. On their arrival the Channel Islands authorities enacted the advice of the UK government to 'continue administration.' They gave their own interpretation to this advice through their pursuit of a policy of correct relations, which entailed strict abidance by principles of law. The main watershed of the Occupation occurred in summer 1941, when Hitler assigned a priority status to the fortification of the islands. Over the following two years they were turned into the most heavily fortified section of the Atlantic Wall. One effect of the fortification program was a radicalization and tightening of the regime. Together with the troops, the islands now also played host to thousands of foreign workers - the majority of them forced. Food shortages, restriction of movements, and security alerts combined to increase the pressure on the civilian population. The Germans sought to ease population pressure by singling out individual groups and deporting them to internment camps. The largest of these deportations took place in September 1942. Earlier, in June 1942, the Germans had confiscated islanders' radios, a measure that sparked a movement of defiance, as a result of which islanders were sent to prisons and concentration camps. When the islands were cut off from France in 1944, the German garrison refused to surrender. The final period of the Occupation was characterized by hunger, but also an unprecedented Red Cross relief operation that would save the population from starvation. The Channel Islands were the last territory to be liberated from German occupation, on May 9, 1945 (Sanders 2005).

Viewing the challenges of Occupation through the lens of dirty hands goes against the historiographical consensus, which bestowed a positive connotation on resistance only. When Jacques Semelin wrote his pioneering Unarmed against Hitler (1993), he, like practically all historians of his generation, chose the resistance paradigm as his 
default position. Framing his study around cases of qualified civilian resistance, such as the Dutch General Strike of 1941 or the grassroots efforts aimed at rescuing persecuted minorities, he discounted activities that did not challenge the occupier frontally or which were subject to ambiguity - regardless of the effects they may have had. Particularly taboo in the scientific discourse were the activities of collaborators, as collaboration was considered a more or less undiluted version of evil. According to Robert O. Paxton's paradigmatic history of Vichy France (1972), the presence of the regime brought no benefits to the French; quite to the contrary, Paxton argued that it made matters worse for them, and that they would have been better off without Vichy. The argument mirrored Hannah Arendt's earlier take in her Eichmann in Jerusalem (1963), in particular her controversial comments on the scale and the speed of the execution of the Holocaust, which she argues would not have been possible without inputs from Jewish community leaders, followed by the argument that bureaucratic chaos and disorder would have resulted in a significantly lower number of victims.

Generalizations about collaboration as the ultimate (or penultimate) stage of evil have become increasingly untenable. The problem with the collaboration narrative is that it conflicts with historical fact. If we focus on the most eloquent and most widely debated example, the Holocaust, we will find that victimization rates were higher in countries where German rule was direct than in those countries where national governments engaged in a policy of state collaboration. ${ }^{3}$ The only variable capable of accounting for this persistent difference is 'principal agent problems [that] had a "negative" effect on the implementation of Nazi policy' (Hollander 2011) or, in other words, the presence of precisely these collaboration regimes. The key omission in this respect is that the high level of organizational and institutional differentiation of modern states and bureaucracies did not work in a linear manner, merely propping up the Nazi enterprise of exploitation, submission, and persecution (Liberman 1996), but that it could also benefit centrifugal forces. As we have seen with regard to the European Jews, continued government did not automatically decrease chances of survival in the aggregate, just as state collapse or disorder did not automatically increase them. The case of Denmark, run by a collaboration government, offers a good illustration: here the entire Jewish population was saved. At the same time, low levels of cooperation with the Nazis and high levels of civilian resistance did not necessarily translate into what one would normally expect to be a key objective of such resistance - that is, the rescue of the Jews. A comparison of the Netherlands and Norway, two directly occupied countries where the civilian resistance factor was prominent, with Denmark and France, two countries where it was lower (due to the continued presence of collaborating governments), produces a paradox: Jewish survival rates in Denmark and France were significantly higher than in the Netherlands and in Norway (Hollander 2011).

3. Indirect occupation regimes were characterized by power-sharing agreements limiting German interference to security and policy initiatives, and formal monitoring of the local administration, but they lacked the routine issuing of direct German orders to the lower echelons in the administration. This 'state collaboration' allowed home-grown institutions to deploy initiative and issue instructions to local administrations, which could be subject to interpretation. Naturally, the German authorities had the power to bypass any agreement and issue direct orders to local administrations, but this had a specific political cost: it could cause an upset with the respective national government and torpedo the overall effectiveness of the occupation regime. There were, then, limits to what could be obtained through brute force. This was a particularly important consideration in those cases where the Germans had a vital economic, political, or propaganda interest in maintaining semi-independent national governments and institutions. 
While a smaller proportion of Jews arrested and deported to the camps - this is what happened in France - in no way exonerates Vichy guilt, the Paxtonian paradigm, which argues that collaboration was the greater evil, loses much of its potency. The remaining question is whether deontological ethics should lead us to dismiss the potential of collaboration for having constituted a lesser evil. This absolutist stance is hard to maintain if we base ourselves on Walzer and Michael Ignatieff, both of whom argue in favor of the permissibility of dirty hands in cases of supreme emergency (Ignatieff 2004, pp. 1-12; Walzer 2004, pp. 33-50). This stance is particularly compelling where the dirty hands of collaboration led to more positives than could be obtained through outright resistance. The devil is in the detail, and only a case-by-case assessment can provide clarity.

Defining a benchmark for best possible outcomes has to take into account that complex problems involving multiple stakeholders rarely concur with the luxury of an ideal, clear-cut solution and are more likely to call for an Aristotelian golden mean. The principal constraint in this particular situation was to solve the contradiction that good government not only benefited the occupied, but also the Nazi occupier. The action of the civilian authorities therefore had to be consistent with limiting the windfalls the occupier might reap from collaboration to the minimum. At the same time, it had to cater to the legitimate disposition of those patriotic citizens who felt uneasy about collaboration, allowing them forms of disapproval, however limited; and it had to avoid hasty sacrifices of the collective safety and well-being of the population. A framework for dealing with this type of quandary exists in fair-share principles, the idea of a correlation between an actor's leverage over outcomes, on the one hand, and the moral obligation to use such leverage for positive impact (fair share), on the other (Santoro 2000, pp. 143-158). A corollary of this is the duty to build coalitions for collective action, wherever this is possible. Regarding those parts of occupied Europe where officials had margins, the golden mean was then situated in a triangle between a moderate good government strategy, a moral obligation to resist (where important, non-negotiable principles were at stake), and a duty to avoid needlessly sacrificing or endangering the lives of the innocent. The last two sides of the triangle can be illustrated through resistance efforts in Denmark and Norway: the Allied destruction of the heavy water production facility in Vemork, Norway, was a moral obligation, for the risk of Nazi Germany building nuclear weapons had to be eliminated at all costs. Despite the extremely high stakes (which could have excused a less considerate approach towards civilian collateral damage), the Norwegian SOE operatives responsible for sabotaging the plant in 1943 and destroying the stock of heavy water in 1944 went the extra mile in order to allay German suspicion about the possibility of an inside job and deflect attention away from the civilian population; they also made every reasonable effort to minimize the number of civilian casualties that their sabotage entailed. Meanwhile, in occupied Denmark assassins working for the Resistance targeted around 400 Danish Gestapo collaborators, but left Germans entirely out of the game, in order to avoid German reprisals against Danish civilians (Bennett 1999, pp. 249-256; Nationalmuseet n.d.). As can be attested through multiple examples elsewhere in occupied Europe, such a responsible approach was far from the norm (Garrett 1993; Bennett 1999).

Channel Islanders were in the fortunate position that they enjoyed some margin of freedom. These margins were due to the fact that the Germans considered them their racial equals, but also that German rule in the islands was indirect, similar to the situation in Vichy France or in Denmark. On the one hand, such an indirect occupation regime catered well to leaders' moral responsibility to keep their communities out 
of harm's way; maintaining this privileged regime could justify a certain measure of dirty hands (Walzer 2004, pp. 33-50). The moral downside, however, was that the natural interest of the occupied in maintaining law and order (rather than growing anomie and anarchy) clashed with the fact that good government benefitted not only them, but also the Nazi occupier. The second downside of taking this leadership call was that it could function as a moral trap, requiring ever-greater dirty hands from the occupied, so that they could continue to benefit from preferential treatment. Safeguarding the greater good through dirty hands was a slippery slope that could very easily lead to a race to the bottom. This indicates that there could be more or less dirty hands involved.

What were the underpinnings of islanders' dirty hands? An integral part of any attempt at limiting the amount of dirty hands required was to arrive at a correct analysis of the situation. But the Occupation was, if we use Keith Grint's catchphrase, $v u$ jadé, a wicked problem for which there was no precedent. Wickedness is a term applied to problems that are particularly intractable or complex. Such problems present no clear relationship between cause and effect, and they often have no stopping point. For this reason, tackling a wicked problem through a tame solution produces secondary effects that amplify the seriousness of the original problem. For a leader, the trick in gaining leverage is to have the courage to resist coming up with the pretense of an immediately workable solution (Grint 2010, pp. 15-17).

The first notion deluding civilian leaders in the islands into doing precisely this was their firm trust in the legal foundation of the Occupation, the Hague Convention. Of the latter, John Leale, the second president of the Guernsey Controlling Committee, stated that it best safeguarded islanders' 'rights and interests as British people.' This quasi-religious faith was not deserved: the Convention represented a lukewarm international minimum standard of rules of engagement, on whose agenda protection of civilians did not figure very highly (Greenwood 2000). As a consequence, a large amount of legal space requiring definition remained void, enabling an occupier to bestow upon the Hague rules the interpretation that best suited him. Sticking to international law did not take into account the volatility of the environment, nor the fact that the islands' authorities were dealing with an occupier who had no interest in considerations of justice and a half-way acceptable rule of law. Finally, the Hague rules could undermine the civilian leadership, as their application often looked like assisting the enemy (Sanders 2005, pp. 69-70 and 92); they also gave a false feeling of security.

The second vector of the islanders' tame solution to the complex problem of occupation was their policy of correct relations with the Germans. Increasing leverage through relationships with German commanders that went beyond the strict minimum necessary to administering the territory under occupation was not a bad move as such, if one understood its limitations. However, relations that became too cordial did not make the most of British prestige, and thus reduced leverage in the long run. Second, tying oneself to a standard as ambivalent as correct behavior is a serious mis-step, as it places the burden of proof on the weaker party and sets the stronger party's expectations too high.

Finally, there was the question whether a gentlemen's agreement was possible with German commanders, many of whom were anything but genuine good-faith negotiators. Even if islanders could not be expected to know much about the polycratic nature of the Nazi regime, characterized as it was by power contests, interloping layers and levels of authority, and deliberate confusion over areas of responsibility, it is common sense to hold back with trust when dealing with an unknown variable.

4. TNA.HO.45/22424. Report of the President of the Controlling Committee on the activities of the Committee during the German Occupation, May 23, 1945. 


\section{COMPARING LEADERSHIP CHOICES IN GUERNSEY AND JERSEY}

On these three counts, the choices made in Guernsey were particularly impetuous. From the beginning, Ambrose Sherwill, the Attorney General of Guernsey and first President of the Controlling Committee, endorsed a hard line for locals earmarked as troublemakers, ${ }^{5}$ and a soft line with regard to the German occupier. Motivated by the desire to shield the civilian population from calamity, the new social contract in occupied Guernsey was formulated a few days before the arrival of the German occupying force, when John Leale, the other leading member of the Controlling Committee, declared:

Should the Germans decide to occupy this Island, we must accept the position. There must be no thought of any kind of resistance, we can only expect that the more dire punishment will be meted. I say this, the man who even contemplates resistance should the Germans come is the most dangerous man in the Island [sic] and its most bitter enemy. The military have gone. We are civilians. ${ }^{6}$

Once the Germans were in occupation of the island, Sherwill entered into close contact with Major Lanz, the first German island commandant. Sherwill's vision on the principle of abidance by standards of international law took mutual relations to a level where, some days into the Occupation, he stated, in a local press announcement, that these were not merely "correct [, but] cordial and friendly."7

This orientation in no way counted in the volatile environment, for Sherwill's scheme soon collapsed; the principal reason being that cordial relations in no way covered the inevitable loyalty problems that arose out of their very operation. This is consistent with what has been said about the secondary effects of tackling wicked problems through tame solutions.

The trigger for the early crisis in islander-occupier relations in Guernsey were the raiding parties that the British military started sending to the island, a fortnight after the German arrival. These raids were conducted in a very amateurish manner and they raised German suspicion that islanders were scheming behind their backs. At the end of July 1940 two British servicemen, Philip Martel and Desmond Mulholland, whom the British military had landed more than a fortnight earlier but then proved unable to ferry off the island, contacted Sherwill in order to arrange their surrender to the Germans. This request was nothing extraordinary in itself, save for the fact that both had landed in civilian clothes, which, technically, made them spies. To save their lives (and those of their helpers) Sherwill engaged in a double game with the Germans. The problem of having set German expectations too high now came to the fore. While Sherwill managed to pull off the surrender of the two men without an incident, albeit after having fitted them with uniforms from a local stockroom, he sensed that he would not be so lucky should such a scenario repeat itself again (Cruickshank 1975, pp. 90-91). Having already tried to solve his dilemma as a senior administrator responsible for the safety of islanders by reinforcing internal police

5. In June 1940 members of the island police force called on potential dissenters, and asked them to 'tone down' for the duration, TNA.HO.144/22237. MI19. Report no. 2507 'Guernsey Side Lights on Island Affairs', November 20, 1944; 'Excerpts from private letter of Guernsey Commission Agent brought over by informant 2503/2503A', n.d.

6. IWM. Documents.13409.Dening 9. Force 135, I(b). Report 'Resistance during the Occupation', n.d.

7. IWM.Documents.13409.Dening 4. Sabotage and Betrayal, Unknown author (Guernsey), n.d. 
surveillance, Sherwill now stepped up his efforts to create further goodwill. These efforts included his famous August 7 speech, at the first States meeting in the presence of Lanz; with its specific reference to making the Occupation a 'model to the world,' the two pillars of which were to be the 'tolerance ..., courtesy and correctness' of the German military, and the 'dignity ... and exemplary behaviour' of the civilian population. ${ }^{8}$ Other gestures were more heavy-handed. An example was the case of a manager at Le Riche's grocery establishment, reported to the German authorities for having reprimanded an assistant who ignored local customers and gave precedence to Germans. Guernsey then passed an ordinance under which islanders could be charged with 'uttering words likely to cause a deterioration of relations between the occupying forces and civilian population' (Sherwill 2006, p. 140). Sherwill later claimed that the island authorities had tried to prevent worse from happening to the man, by charging him in their own court, but we might want to be cautious in following him along this line. ${ }^{9}$

Sherwill's attempt to mediate finally unraveled in September 1940, when he got wind of two other British servicemen stranded in the island, native Guernseymen Hubert Nicolle and James Symes (Sherwill 2006, p. 146). As their predecessors, they had landed in civilian clothes and they were prepared to surrender, if German assurances could be obtained that no reprisal action would be taken. This time the matter was a lot more delicate, however, as Nicolle was the son of a Guernsey government cadre. Any direct involvement in the surrender on the part of Sherwill would immediately arouse German suspicion of a spying ring. The details of supplying the two men with uniforms and arranging their surrender were therefore left to others. Sherwill had only one way in which he could weigh in on the outcome: his close relations with the German Kommandant. The evidence of the continued presence of British military personnel in the island became hard to ignore when the Germans arrested a third British officer, Captain Parker, who was landed in Guernsey to liaise with Nicolle and Symes. Major Bandelow, Lanz's successor in Guernsey, may have sensed that Sherwill knew something about the goings-on, but his suggestion, to Sherwill, to publish a joint communication in the local press, which included an amnesty deadline for the surrender of British military personnel still at large, in exchange for their surrender, seemed like a golden opportunity out of the dilemma. Without giving the game away, Sherwill accepted the offer to publicize the amnesty deadline. Nicolle and Symes then surrendered before the expiry of the deadline, on October 21, 1940. However, in a spectacular about-face, the German side then reneged on Bandelow's promise and arrested and transported 13 people to Paris, including Sherwill, where they had to face a charge of espionage. The hardened German policemen Sherwill now had business with soon called his bluff, claiming that he had given the German authorities the impression that he was their man, and accusing him of betrayal. Sherwill refuted the allegation that he had duped the Germans, but he also realized that he had committed an error in not having made it unmistakably clear to the Germans from the very beginning, that in case of conflict of interest his loyalty to his country would always trump his loyalty to the occupying force. ${ }^{10}$ As he would write later, when the interest of one's

8. 'Report delivered to States of Guernsey by A.J. Sherwill, 7 August 1940', reprinted in Sherwill (2006, p. 272).

9. IWM.Documents.13409.Dening 4. Sabotage and Betrayal, Unknown author (Guernsey), n.d.; for Sherwill's version, see Sherwill (2006, pp. 139-142).

10. IA.G 01-07. Typescript, 'Extract from the Commentary of the Manual of military law, issued by the War Office, 1929 Edition', n.d. 
country or the safety of one's countrymen are at stake, one must, if necessary, 'lie and lie' (Sherwill 2006, p. 92). In dirtying his hands Sherwill had to look both ways: it was not sufficient to bring his own side online; the lesson also needed to be applied to the Germans.

Although the espionage charge was dropped in December 1940, thus bringing the affair to a relatively lenient conclusion, it created a debt towards the Germans, which islanders would have to repay. Ruffling feathers was even more out of the question from this point onwards, and this set the tone for the remainder of the Guernsey Occupation. The Germans immediately took advantage of this new situation and raised the stakes. Throughout 1941 they continued to harass the island population with threats of reprisals, mostly in connection with the continued hypothetical sheltering of military personnel, the real enough sabotage of cables, and the appearance of painted V (for Victory) signs in response to a British radio campaign. ${ }^{11}$ Under the weight of the circumstances, John Leale, Sherwill's successor as President of the Controlling Committee, increased the hard-line rhetoric of no resistance by one notch. Painful as his intercessions were to the patriotically-minded, he still managed to resist overstepping the invisible moral line. ${ }^{12}$ The Rubicon was only crossed by Victor Carey, the Bailiff, who submitted to German hectoring, in July 1941. He did this by offering a $£ 25$ reward, in the local newspaper, for anyone willing to volunteer information on a V sign, over which the Germans had cooked up their customary brouhaha.

Besides showcasing the wickedness of the Occupation and the resultant inadequacy of a tame approach, the Nicolle-Symes affair shows how this brought out negative secondary effects and thereby increased the need to rely on further dirty hands. This is in line with the overall notion of tackling wicked problems via tame solutions, which amplifies their noxiousness. Without the tame solution of correct and cordial relations, Sherwill's loyalty problems would not have occurred; it would not have been necessary to pass ordinances and criminalize certain types of behavior, as seen in the case of the Le Riche's manager; and Bailiff Carey may have seen less of a reason to exhort islanders to a practice of denunciation that equaled an admission of defeat and that would erode public trust.

Other conspicuous differences between Guernsey and Jersey were the paternalistic, sometimes even patronizing rhetoric and tone that characterized official communications with the general population in Guernsey (Sanders 2005; 2010), which had no equivalent in Jersey. Contrary to Jersey, Guernsey also passed legislation such as a German Order requiring Jews to wear a six-pointed yellow star, in June 1942 (Cohen 2000, p. 41). Finally, the little active resistance there was had a harder time gaining a foothold in Guernsey than in Jersey. Whereas a rudimentary resistance movement can be argued to have emerged in Jersey, the name of the game in Guernsey was symbolic resistance, exemplified, in particular, by the illicit spreading of British radio news (Carr et al. 2014).

The key dirty hands case in Jersey, offering illustration of the difference in approach, concerned Frederick Page, a Jerseyman reported to the Germans for wireless reception, a practice considered a serious offence by the Germans. The wireless offence had come to the attention of the local police through a tip-off from a member

11. IA.FK 01-11. Feldkommandatur 515 (Knackfuss) to the Bailiff of Guernsey, and to Nebenstelle Guernsey. Re. Plakatierung einer Proklamation, April 5, 1941.

12. After a cable sabotage in March 1941, Leale said that anyone who had wished to do so could have left the island the year before; he concluded that those who stayed had accepted the position and would 'act as good citizens' (see Guernsey Star 1941). 
of the public. ${ }^{13}$ The police could, of course, have looked the other way, but this would have exposed them to the risk of being themselves denounced to the Germans. In this situation Centenier Garden, the officer in charge, made an informal approach to his hierarchy, the Attorney General of Jersey, Charles Duret Aubin. The latter gave him the advice that he 'must decide with his own conscience where his duty lay.' Under a German order passed in 1942, Duret Aubin was obligated to signal all anti-German occurrences; he therefore added that he would have 'no alternative' but to pass on the matter to the Germans, if he did receive a formal police report. ${ }^{14}$ When Garden put the matter to his colleagues, their unanimous opinion was that they had a duty to the community and that they should not risk the police force coming under direct German control. A report was then sent to the Attorney General, who forwarded it to the Germans. Page was arrested and tried, together with a number of other men, and died in a German prison in 1945.

Quizzed about the case after the war, Duret Aubin presented it as force majeure, thereby passing under a veil of silence that the dilemma was partially or even entirely self-inflicted: the slippery slope that had brought the local police into a situation where they could be forced to report a fellow islander, for something that was not a crime under the law of the island, could have been anticipated (Sanders 2005, pp. 62-66). In addition, this was not the only case where the authorities surrendered groups or individuals to safeguard the greater good. The authorities' compliance may have been motivated by the desire to avoid paying the political price that better foresight would have entailed. Notwithstanding these misgivings, however, doesn't the fact that a resistance-minded policeman ${ }^{15}$ would confide in the Attorney General, without fear of reprimand, on a problem of conscience related to his official duties, tell an astounding story about the level of social trust that still existed in Jersey, as far into the Occupation as mid-1943? If, under occupation law, Duret Aubin had to signal all anti-German occurrences, wouldn't this have included his conversation with Garden? And didn't he indicate that he would only forward the case to the German authorities if he received a written report? This indicates an important willingness to look the other way in other, more favorable circumstances. It also points in the direction of the Jersey authorities having understood the double-binds in which the Occupation placed all officials.

A similar intimacy between leaders and followers may have been intended for Guernsey. But it collapsed in the wake of the Nicolle-Symes affair, and by 1941 the approach had hardened considerably. The social contract adopted in Guernsey can be resumed in the phrase of a Guernseyman who escaped to England in August 1943. The latter stated in his security service debrief that the authorities of his island 'would not even close their eyes to instances of passive resistance.' ${ }^{16}$ This proactive discouragement of opposition made a considerable difference. It contributed to the erosion of leadership legitimacy, which became a fait accompli by the time of Bailiff Carey’s public £25 reward in 1941 .

The creeping loss of legitimacy can also be gauged from the preliminaries leading up to the major civilian trial in occupied Guernsey, in early summer 1942. This was the

13. JAS D/Z/1943/19. Centenier Garden to Attorney General, June 2, 1943.

14. JAS D/Z/1943/19. Memorandum, Attorney General, August 4, 1945.

15. Garden is mentioned as such in the intelligence debrief of three Jersey escapees, TNA. HO.144/22237. MI19. Report no. 2510(S), 'Jersey Reliable Personalities. Further interrogation of three Jersey escapees', November 27, 1944.

16. TNA.HO.144/22834. Memo, J.T.D. Hubert, August 23, 1943. 
second of two trials concerning the pilfering of German and islander-owned depots by members of the island police force, between autumn 1941 and early spring 1942. The raids on the German depots had been the object of a military trial, in April 1942, and had led to the conviction of seventeen policemen. Once they completed their trial, the Germans handed over the case to the Royal Court of Guernsey, for prosecution of the civilian charges. Although there was evidence that the statements used in both trials were unreliable, as they had been extracted through third-degree methods, the civilian authorities went ahead with this trial and convicted nine of the ten indicted. After the war eight of these asked for their civilian convictions to be overturned, claiming that the island authorities had pressured them into pleading guilty, in order to avoid an early collapse of the civilian trial (and embarrassment to themselves); and that the political context had rendered them unable to present the genuine motive of their action - that is, sabotage of the enemy's war effort.

The official line on this event has been that the island bosses were motivated by paternalism, and that trying the civilian charges in the island court prevented worse, such as having to send the men back to the Germans for a second trial. Contrary to this myth, however, the policemen and their hierarchy had been divided by an ever widening ocean of incomprehension since even before the Occupation. Following the outbreak of war in September 1939, many in the island police force - which contained several ex-servicemen - had wished to enlist in the armed forces. While it is unclear whether pressure was exerted to compel the men to remain at their posts, ${ }^{17}$ the fact is that by the time the Germans invaded, none had joined up. Once the trap shut, many of the men began to realize their predicament, and regretted their decision. Policing their fellow islanders in the interest of a policy of frictionless collaboration with the enemy was not something they had bargained for. Resentment against officials for putting them in this situation mounted. Torn between two antagonistic but equally legitimate positions - the duty to do something for King and Country, on the one hand, and the call to ensure that the Occupation stayed frictionless, on the other - the police force became confused as to where their duty lay. One of the men described the situation they faced in the following terms:

The Police Force ... was in a difficult position, because we had to convince the Germans that we were working for them, at the same time as we were ... doing our best not to help them. ${ }^{18}$

In order to come out of this situation well, the authorities had to recognize the profound implications of this difficult and unprecedented situation for all public officials; they had to use their discretion to the full; their subordinates needed guidance in order to tackle the worst ethical pitfalls; and it was imperative to maintain social trust. Enforcing blind obedience could not be relied upon in this situation; what was needed were additional informal arbitrages. The police in both islands were in a particularly acute predicament because they were the best-informed collective group of islanders.

17. Harper claimed that Inspector Sculpher prevented him from joining HM forces in 1940, IA. AQ 1214/17. William M. Bell Collection. Affidavit Harper, January 10, 1950 (copyright in the estate of Jack Harper). As to Tuck's description there is some conflict: in the 1942 civilian trial he stated that the men received no straight answer to the question as to whether they had to 'stay' or could 'join' (HM Stationery Office 1952, p. 33). In their 1950 memo to Advocate Randell, however, Tuck and Bailey contended that the men were prevented from joining, through a threat of forfeiture of their pension rights, TNA.HO.284/6. Letter of Mess. Tuck and Bailey to Advocate Randell, July 26, 1950; also Bell (1995, p. 133).

18. IA.AQ 1214/17. Affidavit Short (date missing, presumably 1951) (copyright in the estate of Frederick Short). 
We know that it was no secret to the police in Guernsey that often two measures were being applied. They had first-hand knowledge of the black market trades in the island; and they also knew who was working the system to his or her advantage, and how. ${ }^{19}$ At the same time, they experienced the deprivation suffered by islanders without the right connections to get them through these difficult times (Bailey 1961, p. 16) ${ }^{20}$ Men in this kind of exposed position need to be led in a particular manner; invoking strict obedience to authority can no longer suffice. This is where the crux of the problem lies, for this cluster of men had no guidance on how to behave in the political vacuum that was the Occupation, and in particular how to navigate the Scylla und Charybdis of legitimacy. The inability of their leaders to explain why they could not afford to tackle the Germans head-on led to a void in communication. The inclinations in the force emerge clearly from a memo drafted by the policeman spearheading the postwar action for rehabilitation, Frank Tuck. It leaves no doubt that the police had wanted to do anything but open the doors to German officers and salute them. ${ }^{21}$ Another of the men, Kingston Bailey, stated that, as a branch of executive government, the police became practically useless: 'I turned a blind eye on almost everything, completely ignoring our Police [sic] duties and averting my attention, as far as possible, to the Germans. ${ }^{22}$ From there, things went adrift, and the police started to take things into their own hands. Soon enough they were not only at the forefront of anti-German sentiment, but also of anti-German action. Bailey dated the commencement of his own petty resistance with Tuck in March 1941, and they were soon followed by other members of the force (Bailey 1961, pp. 15-16; Bell 1995, pp. 106-108 and 133-138). ${ }^{23}$ The embryonic movement was then galvanized into further action by the radio broadcasts of Douglas Ritchie (alias Colonel Britton), a BBC radio agitator exhorting populations across occupied Europe to engage in 'gentle disruptive activities' against the occupier. Britton's missives fell onto exceptionally fertile ground among the men of the Guernsey police force:

We ... felt that he was talking to us and inciting us to action. After all, he was talking to us in English, and we were the only part of the realm occupied. Why would he speak in English to the French, the Poles, the Dutch, or the Belgians? ${ }^{24}$

\section{SOCIAL CAPITAL AND LEGITIMACY}

Much of the difference in approach between the two islands owed to environmental pressures. Strategically, Guernsey was more valuable than Jersey, and therefore sustained a heavier German military build-up, with all that this entailed for the civilian population. This drained the life-blood of a body politic that had already suffered a demographic cataclysm during evacuation week (June 1940), when a panic movement

19. IA.AQ 1214/17. Affidavit Tuck, February 28, 1951 (copyright in the estate of Frank Tuck). 20. Several such cases appear in the men's postwar affidavits, IA.AQ 1214/17. Affidavits, passim (various copyright holders).

21. TNA.HO.284/6. Letter of Mess. Tuck and Bailey to Advocate Randell, July 26, 1950.

22. IA.AQ 1214/17. Affidavit Bailey, February 10, 1951 (copyright in the estate of Kingston Bailey).

23. IA.AQ 1214/17. Affidavit Harper, January 10, 1950 (copyright in the estate of Jack Harper); Affidavit Burton, February 1951 (copyright in the estate of William Burton).

24. IA.AQ 1214/17. Affidavit Harper, January 10, 1950 (copyright in the estate of Jack Harper). 
swept the island, as a result of which 40 percent of the civilian population evacuated to England.

Structure, however, should not be made to account for all. Any proper analysis also has to factor in the leadership's inappropriate handling of the wicked problem of occupation, which eroded social trust.

Why is trust so important, in terms of determining the ability to put up a fight? In his book Unarmed against Hitler, Jacques Semelin (1993) found that civilian resistance blossomed in institutional contexts where a tradition of democracy and pluralism had dominated before the war. The enablers of resistance were two key components of social trust, social cohesion, and leader legitimacy.

In scientific discourse, social cohesion and social trust are often subsumed under the term social capital (Forrest and Kearns 2001). This denotes 'social networks and associated rules of reciprocity which ... create both individual and collective value' (Martinez and Soledad 2005). According to Fukuyama (2001, pp. 16-17) and Rothstein (2003, p. 49), social capital is the result of reiterated prisoner's dilemma games (history of play), which increase trust over time. The creation of value revolves around the idea that reciprocal trust is related to virtues, such as honesty, which diminish transaction costs (Martinez and Soledad 2005). A crisis or duress situation submits social capital to a shock, as it is difficult to build relationships or because previous bonds are weakened. As a result trust, and social capital, may reduce or dissipate, and with it the associated social and economic benefits (Fowler and Etchegary 2008, p. 337). This entails a critical imperative to safeguard social capital in duress situations (Forrest and Kearns 2001; Osgood and Ong 2001; Rothstein 2003).

The novel argument that is made here is that social capital and legitimacy are not merely important factors for resistance, as Semelin (1993) argued, but that, by inverse inference, they could also have a bearing on collaboration. In fact, both social capital and legitimacy were critical to lowering dirty hands within collaboration, and to attaining superior ethical leadership performance.

Some might argue that social capital depletion in Guernsey was the result of the worsening of the environmental outlook in the wake of the Nicolle-Symes affair. This overlooks, however, that social capital depletion was triggered before the arrival of the German force (Sanders 2010). That so many left in June 1940 can be put down to wavering and miscommunication on the part of the British government, but also to the lack of resolve of the Guernsey leaders. When a similar panic had threatened in Jersey, the Bailiff of Jersey had decided to make a public declaration which calmed the waves: out of a total Jersey population of 50,000, only 6,600 would leave, and Jersey's population structure retained its prewar character (Cruickshank 1975, pp. 41-45; Sanders 2005, p. xx). By contrast, in Guernsey families were torn apart, and scores of elderly and vulnerable people remained behind, many of whom fell victim to a significant leap in mortality rates, in 1941-1942 (Sanders 2005, p. 152). Social capital was further eroded by the decision of the collective leadership of Guernsey to put their faith in the rules-based framework of the Hague Convention, zero tolerance for locals earmarked as troublemakers, and a goodwill strategy of cordial and correct relations with the German occupier.

Legitimacy, on the other hand, relates to the fact that social actors and entities act in conformity with a political, legal, and constitutional regime whose rules and norms they respect. Especially unusual, anti-systemic, or anti-conformist behavior - such as resistance - should never be taken for granted, only because, in retrospect, it turned out to have been morally more adequate than acquiescence. In fact, such behavior can only be expected if the legitimacy of the regime to which individuals are subject is 
answered in the unequivocally negative; or if key proponents of legitimacy rally the forces of anti-systemic behavior.

The role of legitimacy in developing and strengthening social entities has long been a core theme of social research, before also being taken up by organization studies. As Keyes et al. (2000) found in their theory of positive organizations, legitimate authority has positive effects on employee well-being and on business outcomes. Legitimacy creates a self-sustaining virtuous cycle where any positive effects feed back into the legitimation of leaders. Although the present author does not disagree with this, it nevertheless strikes him as only half the story. The fact is that legitimacy is the crucial lever of social capital; and that it sways social capital in a particular direction. The reason for this lies in the context-dependence of social capital (Bourdieu 1986; Osgood and Ong 2001, p. 208), for social capital has a potential downside, represented by the term negative social capital. This relates to the fact that discrimination, organized crime, corruption, honor killings, and other such criminal, illegal, or unethical practices also rely on (negative) social capital, generated by code of honor, bonding, kinship ties, or mutual trust; but that the ends are not moral. If we take the case of the occupied Channel Islands, then we will find that (negative) social capital in favor of conformism (and the stifling of opposition) held an uneasy balance with (positive) social capital ready to weigh in on the morally more desirable option of protest, defiance and resistance to an unjust regime. This is where legitimacy made the difference. Because of the critical nature of legitimacy, loss (or lack thereof) could serve as a catalyst for social capital depletion.

Applied to Guernsey, we will find that the first vector contributing to legitimacy loss was the lack of unified leadership, or dual power. This created internal contradictions and played into the hands of those Germans who saw greater utility in the iron fist than in the velvet glove. Whatever one might think about his tame strategy, the only Guernsey contender who could have matched the general leadership abilities of Alexander Coutanche, Bailiff of Jersey since 1935, was Ambrose Sherwill. He showed his colors in summer 1940, when he saved four British officers from being shot as spies. ${ }^{25}$ Sherwill was, to all practical intents, the top man in Guernsey, conducting Bailiff Carey's executive business on top of his official duties as Attorney General and President of the Controlling Committee in Guernsey. ${ }^{26}$ He did have one important handicap, however: he lacked the undivided authority and prestige of Coutanche who was both Bailiff and President of the Jersey Superior Council. The arrangement between himself and Carey meant that Sherwill could not avail himself of the same degree of teamwork as Coutanche, who worked in tandem with Duret Aubin, the Attorney General of Jersey. This tandem saw Duret Aubin do most of the low-level pleading, while Coutanche remained inaccessible to any but the most high-ranking Germans - the big gun, ready to be wheeled out in extremis. This game contained an element of political showmanship aimed at leveraging influence with those German officials whose foreign policy sensitivities or Anglophilia could be exploited. Sybil Hathaway, the Dame of Sark, employed very similar stratagems. Already during evacuation week her firm authority avoided scenes of panic as seen in the other islands. The other advantage the Dame used to great effect was her knowledge of Germany and the Germans, whose language she spoke fluently, and her noble extraction,

25. His specific role was acknowledged in Home Office correspondence, in 1944, TNA.TS.26/89. J.A.R. Pimlott (HO) to J.M. Martin CVC, September 18, 1944.

26. IWM.Documents.13409.Dening 4. 'Report by Major Lanz, 216 ID, the first German Commandant,' 1940. 
which enabled her to see eye-to-eye with her German peers, of whom there were a considerable number in the islands (Marr 2001, p. 320).

Similar things must have been intended for Guernsey, but failed because the Bailiff resisted encroachments onto his prerogative by the Controlling Committee; at the same time he lacked the charisma and energy of a Coutanche or Hathaway. ${ }^{27}$ The duality of power was not specific to Sherwill's short period at the helm of the Guernsey Controlling Committee, but continued in the four-and-a-half years during which it was led by his successor, John Leale. As a result, the leadership in Guernsey never worked in unison.

The second vector that contributed to the loss of legitimacy was the handling of the legitimacy issue on a wider level. To understand legitimacy during the Occupation, it is crucially important to consider legitimacy watersheds (Conway and Romijn 2004). These are notoriously difficult to define, as both resistance and collaboration could be legitimate up to a certain point. As a general rule, a regime of foreign occupation may have legality on its side, but not legitimacy. To be sure, the German occupiers followed this pattern and lost any legitimacy they may have had to begin with relatively quickly. In occupied Europe, legitimacy was therefore vested either in the collaborating governments or the rump administrations that continued to work under the instructions of the occupying authorities; or in the exiled governments, most of which operated out of London. Often, the association of collaborating bureaucracies and German occupier entailed a rapid loss of legitimacy - if they had had any to begin with - and the rapid rise of movements of opposition that sought to fill the vacuum. If we take the examples of Denmark or France, then we notice that the official policy of collaboration retained legitimacy in the beginning, but that this started to decline in 1941-1942, before shifting to the resistance in the second half of 1943. The Danish government then resigned, whereas the Vichy government continued to function, which entailed the loss of its remaining pockets of legitimacy (Peschanski 2004).

In the islands, the battle for legitimacy was less vociferous, but no less convoluted than elsewhere in Europe. Legitimacy in the islands was vested in the collaborating civilian authorities (the British government having advised them to stay behind and continue administration), but it could also be claimed by those islanders invoking the name of the King and urging resistance against the enemy of Britain. The situation was based on a paradox and it opened the door to ambiguity. Rather than shifting from one strand to another as the war progressed, in the islands these two legitimacies existed side by side, a dualism that lasted until the end of the Occupation.

This is not to say that the emphasis could not change. The overall dynamic was composed by the presence of two constituencies: a majority that was opposed to anything likely to irritate the Germans, and amenable to giving in to their demands; and a substantial minority who felt that islanders emerged relatively unscathed from the Occupation not because they respected international law, top-down hierarchy, paternalism, or disciplinary measures, but because they were members of an enemy nation whom the Germans considered their equals. They thought that, used with parsimony, the soft power of British prestige could trump German might in at least some instances. The second group also criticized correct relations as a standard of behavior and demanded a sterner attitude on the part of the islands' authorities.

27. In 1944 a senior administrator, Max von Aufsess, referred to the Guernsey statesmen as 'weaker characters' and to the Guernsey government as less 'politically sound and stable' than Jersey's. Letter to General von Schmettow, September 14, 1944, reprinted in his diary (Von Aufsess 1985, p. 24). 
They anticipated that only this could neutralize some islanders' temptation to pre-empt German demands through anticipatory obedience, thereby setting in motion a vicious circle of self-reinforcing collaboration. The very real danger of this scenario was that it would destroy public trust and lead to the emergence of a mutual surveillance society where denunciation would become a public virtue. This would hand the Nazis on a plate what they couldn't have achieved otherwise: a self-policing environment, on the ruins of an obliterated community. Preventing the scenario of a Hobbesian regression of this type was a very close second, morally, to the priority of assuring the physical survival of the civilian population. For the first two years of the Occupation, the timorous majority had the upper hand over the more daring part of the population. However, the public opinion shift of 1941-1942 that followed the tightening of the regime turned the tables on the majority. In the wake of the wireless confiscation, the arrival of the forced workers, and the deportations of civilians to internment camps, an increasing number of people became, in principle, more favorably disposed to opposition (Willmot 2005). This minority could not be simply overlooked, as it enjoyed significant support. This can be attested through the massive popular movement of defiance, in both islands, that followed the wireless requisition in 1942. The logistical, moral, and material assistance provided to escaped forced and slave laborers, an effort that was particularly strong in Jersey, speaks a very similar language (Sanders 2005).

Throughout, the legitimacy of the islands' authorities was vested in their ability to avoid a contest between the two core constituencies. Such a fatal weakening of the body politic was incompatible with the calling of a responsible leader. Achieving this depended on taking stock of the interests of the two local constituencies, consolidating group trust, and building a new consensus. Public approval seeking not only maintained the feedback mechanism and reinforced leader legitimacy, but it was also a smart move for dealing with a wicked problem. As Grint demonstrates in his book about D-Day (Grint 2007), collective brainstorming or thinking outside the box is far more likely to lead to the dénouement of an intractable problem than authoritarianism. It is also a good antidote for surviving a backlash, if no dénouement materializes after all. Followers will have become stakeholders and any failure will be collective rather than individual.

While plebisciting as a feature of leadership legitimacy can be detected in followership and relationality approaches (Ben-Yoav et al. 1983; Dellve and Wikström 2009; Ospina and Uhl-Bien 2012), the task of arbitrating between the two constituencies and striking a new balance was something of a tightrope walk. As the literature tells us, in a crisis (or duress) context the discourse required to retain (or restore) legitimacy has to be extended from salient stakeholders to the general public (Hasbani and Breton 2013).

How was one to go about navigating a median course between the Scylla of compliance with the occupier and the Charybdis of patriotism calling for something to be done against the enemy? Officials were right in taking a dim view of incidents that could lead to spirals of violence. They could not afford to stir up sentiment that may have encouraged irresponsible hotheads. It was equally sound to give the impression that German law was to be obeyed. At the same time, they could not be strangers to cunning and they had to discreetly point the way; they had to leave no ambiguity about the mainspring of their authority, the Crown; and they had to take good care of not maneuvering themselves into catch-22s. Any good government under occupation required the recognition of Realpolitik and Machiavellian power play, but it could not turn a blind eye to considerations of justice. The basic idea is that of a double game. 
The implicit social contracts developed in both islands attest to the handling of the legitimacy issue. On comparison, we will find that the opportunistic Jersey version (live and let live) was a more adequate response to the wicked problem of occupation. While it was certainly not encouraged, the Jersey leaders were never proactive in rooting out opposition. While open provocation was taboo, islanders were granted the freedom to decide for themselves. The signal given was that those who got into trouble with the Germans should not rely on any assistance; but the overall orientation was to neither encourage nor discourage passive resistance. This took into account the growing despondence among certain people, who might revert to desperate means, if they were not given a lid to let off steam (Sanders 2010).

\section{CONCLUSION}

The article started from the basis of the recognition of the general problem of dirty hands. This notion has been shown to be of relevance to our understanding of a particular historical leadership context: the challenges faced by the civilian authorities of the British Crown dependencies of Jersey and Guernsey during the German Occupation in the Second World War. The case study material profiled in these pages provides evidence of leadership margins in both islands as well as of the operation of dirty hands within the confines of this maneuvering space. Despite similar starting positions, noticeable differences emerged between the two islands with regard to how the leadership space was filled with life. The indication is that there was a somewhat greater reversal to dirty hands by the collective leadership of Guernsey than was the case in Jersey. The two theoretical constructs that were shown to have made sense of these differences are social capital and legitimacy. Both bear a relation to a specific set of leadership skills: the ability to play a dynamic political game, use cunning, assert one's authority, and provide a good mix of courage and prudence; combined with the art of persuasion, oratory, coalition building, and effective communication between stakeholder groups.

In terms of implications this research points to one of the most important leadership quandaries of our time: dealing with uncertainty. Attracting the brightest and the best, capable of making the most astute assessments of any given situation, and fostering a culture of dialogue that will brainstorm the various organizational options can go some way towards managing uncertainty. But while planning and preparation can go a long way in dealing with systemic risk, they cannot foresee the negative side-effects of the unexpected, the black swans. As is the case with the intractability of many of the world's worst problems, the effective solution will not be known, at least not in the short term. An extreme stress or duress scenario will find little use for traditional crisis leadership virtues such as decisiveness, as it will not be known what exactly needs to be done. At the same time, organizations will find themselves under considerable strain, sometimes to breaking point, and there will be an acute need to fight off divisions in order to remain effective. At this point the leadership emphasis will have to shift to maintaining a system's cohesiveness and operational capacity in order to limit the impact of the black swan. That's exactly where social capital and legitimacy come into the equation.

Second, this research exhorts us to bring dirty hands to the core of leadership studies. The interest in dirty hands of scholars operating outside the confines of political philosophy and just war theory has been muted for the most part. The current orientation of leadership studies is such that none of the major theories, whether it 
be transformational, authentic, networked, or relational leadership, integrates dirty hands in any form. The preferred matrix for sketching leadership is still that of wholesome role models with positive leadership attributes; the dark side associated with the exercise of any form of power is routinely framed out. The simplicity and unidimensionality of this bias disregards the gray areas that surround all leadership, thereby missing out on an essential constitutive feature. ${ }^{28}$ The chief justification for proceeding in this way is the idea that dirty hands is irrelevant to areas such as corporate leadership - that it is confined to the domain of high politics. And the general line is that leaders who leave the straight path and dirty their hands in non-political contexts squander our trust and deserve our moral condemnation.

This reading of the twenty-first century leadership challenge is hardly adequate. In the contemporary world, the division between the strictly political and non-political is increasingly clouded. Many of the most pressing contemporary problems require coalitions or stakeholder alliances involving government, business, and civil society. At the same time, global affairs - and this includes international business - have become more competitive and conflictual, due to the emergence of governance gaps where raw power is the order of the day. Duress of this type increases the inclination to override conventional ethical programming, and dirty hands is its natural consequence (Sanders 2012).

Finally, leadership applies across the board. To paraphrase John Adair's keynote address at the 2013 International Studying Leadership Conference in Rome (Adair 2013), leadership today permeates organizational development in all walks of life. There are no leadership-free zones and therefore leadership research cannot be contained within the realm of the well-circumscribed and relatively simple problems present in an area such as corporate strategy; it has to address the wicked problems of new global complexity. The leadership challenge of the future is not merely of a conceptual, operational, or sustainability, but also of an ethical nature.

\section{REFERENCES}

Adair, John (2013). Available at: http://www.demote.eu/wordpress/?page_id=50 (accessed December 11, 2014).

Alexandra, A. (2007). Professional ethics for politicians? In: Primoratz, I. (ed.). Politics and Morality. New York: Palgrave Macmillan, pp. 76-91.

Arendt, H. (1963). Eichmann in Jerusalem: A Report on the Banality of Evil. New York: Viking Press.

Bailey, K. (1961). Dachau. London: Brown Watson.

Bell, W.M. (1995). I Beg to Report: Policing in Guernsey during the German Occupation. Guernsey: Guernsey Press Company.

Bennett, R. (1999). Under the Shadow of the Swastika. New York: New York University Press.

Ben-Yoav, O., Hollander, E.P., and Carnevale, P.J. (1983). Leader legitimacy, leader-follower interaction and followers' ratings of the leader. The Journal of Social Psychology, 121(1), $111-115$.

Bourdieu, P. (1986). The forms of capital. In: Richardson, J. (ed.). Handbook of Theory and Research for the Sociology of Education. New York: Greenwood, pp. 241-258.

Carr, G., Sanders, P., and Willmot, L. (2014). Protest, Defiance and Resistance in the Channel Islands 1940-1945. London: Bloomsbury.

28. One notable exception to this general tendency within the field of leadership is Neal and Tansey's (2010) case study of Rafiq Hariri's dirty hands leadership in post-civil-war Lebanon. 
Coady, C. (2011). The problem of dirty hands. The Stanford Encyclopedia of Philosophy. Available at: http://plato.stanford.edu/archives/sum2011/entries/dirty-hands/ (accessed December 8, 2011).

Cohen, F. (2000). The Jews in the Channel Islands during the German Occupation 1940-1945. London: Jersey Heritage Trust in association with the Institute of Contemporary History and Wiener Library.

Conway, M. and Romijn, P. (2004). Introduction. Contemporary European History, 13, 377-388.

Cruickshank, C. (1975). The German Occupation of the Channel Islands. London: Oxford University Press for the Trustees of the Imperial War Museum.

Dellve, L. and Wikström, E.K. (2009). Managing complex workplace stress in health care organizations: leaders' perceived legitimacy conflicts. Journal of Nursing Management, 17(8), 931-941.

Forrest, R. and Kearns, A. (2001). Social cohesion, social capital and the neighbourhood. Urban Studies, 38(12), 2125-2143.

Fowler, K. and Etchegary, H. (2008). Economic crisis and social capital: the story of two rural fishing communities. Journal of Occupational and Organizational Psychology, 8(2), 319-341.

Fukuyama, F. (2001). Social capital, civil society and development. Third World Quarterly, 22(1), 7-20.

Garrett, S.A. (1993). Conscience and Power: An Examination of Dirty Hands and Political Leadership. New York: St Martin's Press.

Garrett, S.A. (1996). Ethics and Airpower in World War II: The Bombing of German Cities. New York: St Martin's Press.

Greenwood, C. (2000). International humanitarian law (laws of war). In: Karlshoven, F. (ed.). The Centennial of the First International Peace Conference - Reports and Conclusions. The Hague: Martinus Nijhoff, pp. 252-254.

Grint, K. (2007). Leadership, Management and Command: Rethinking D-Day. Basingstoke, UK: Palgrave Macmillan.

Grint, K. (2010). Leadership: A Very Short Introduction. New York: Oxford University Press. Guernsey Star (1941). Extract from Jurat Leale's speech in the States, March 22.

Hannah, S.T., Uhl-Bien, M., Avolio, B.J., and Cavarretta, F.B. (2009). A framework for examining leadership in extreme contexts. The Leadership Quarterly, 20(6), 897-919.

Harris, P. (2001). Machiavelli, political marketing and reinventing government. European Journal of Marketing, 35(9/10), 1136-1154.

Hasbani, M. and Breton, G. (2013). Restoring social legitimacy: discursive strategies used by a pharmaceutical industry leader. Society and Business Review, 8(1), 71-89.

HM Stationery Office (1952). In the Privy Council on Appeal from the Royal Court of the Island of Guernsey between William George Quin and others, and Her Majesty the Queen, no. 10, London.

Hollander, E. (2011). Swords or shields? Implementing and subverting the Final Solution in German-occupied Europe. Working paper, Department of Political Science, Wabash College. Available at: http://papers.ssrn.com/sol3/papers.cfm?abstract_id=1906430 (accessed September 6, 2013).

Ignatieff, M. (2004). The Lesser Evil: Political Ethics in an Age of Terror. Harmondsworth, UK: Penguin.

Keyes, C.L.M., Hysom, S.J., and Lupo, K.L. (2000). The positive organization: leadership legitimacy, employee well-being, and the bottom line. The Psychologist-Manager Journal, 4(2), $143-153$.

Liberman, P. (1996). Does Conquest Pay? The Exploitation of Occupied Industrial Societies. Princeton, NJ: Princeton University Press.

Machiavelli (1965). The Discourses on the First Decade of Titus Livius. In: Machiavelli. The Chief Works and Others. Trans. A. Gilbert, 3 vols. Durham, NC: Duke University Press, pp. 175-529.

Marr, J. (2001). The History of Guernsey: The Bailliwick's Story. Guernsey: The Guernsey Press. 
Martinez, C. and Soledad, M. (2005). Los valores éticos del capital social y su influencia en el crecimiento económico. Informacion Comercial Espanola Revista de Economia, 823 (English summary).

Nationalmuseet (n.d.). Stikkerlikvidering - Modstandskampens blodige byrde. Available at: http://natmus.dk/historisk-viden/danmark/besaettelsestiden-1940-1945/flammen-og-citronen/ modstandskampens-blodige-byrde/ (accessed August 5, 2013).

Neal, M.W. and Tansey, R. (2010). The dynamics of effective corrupt leadership: lessons from Rafik Hariri's political career in Lebanon. The Leadership Quarterly, 21(1), 33-49.

Osgood, M. and Ong, B. (2001). Social capital formation and development in marginal communities, with reference to post-Soviet societies. Progress in Development Studies, 3(1), 205-219.

Ospina, S.M. and Uhl-Bien, M. (2012). Exploring the competing bases for legitimacy in contemporary leadership studies. In: Ospina, S.M. and Uhl-Bien, M. (eds). Advancing Relational Leadership Research: A Dialogue Among Perspectives. Charlotte, NC: Information Age Publishing, pp. 1-40.

Paxton, R. (1972). Vichy France: Old Guard and New Order. New York: Knopf.

Peschanski, D. (2004). Legitimacy/legitimation/delegitimation: France in the dark years - a textbook case. Contemporary European History, 13(4), 409-423.

Rawls, J. (1999). Fifty years after Hiroshima. In: Rawls, J. Collected Papers. Cambridge, MA: Harvard University Press, pp. 565-572.

Rothstein, B. (2003). Social capital, economic growth and quality of government: the causal mechanism. New Political Economy, 8(1), 49-71.

Sanders, P. (2005). The British Channel Islands under German Occupation 1940-45. Jersey: Jersey Heritage Trust.

Sanders, P. (2010). 'Managing under duress' - ethical leadership lessons from the Nazi occupation of the British Channel Islands 1940-1945. Journal of Business Ethics, 93(suppl. 1), 113-129.

Sanders, P. (2012). Is CSR cognizant of the conflictuality of globalisation? A realist critique. Critical Perspectives on International Business, 8(2), 157-177.

Santoro, M. (2000). Profits and Principles: Global Capitalism and Human Rights in China. Ithaca, NY: Cornell University Press.

Semelin, J. (1993). Unarmed against Hitler: Civilian Resistance in Europe, 1939-1943. Westport, CT and London: Praeger.

Sherwill, A. (2006). A Fair and Honest Book: The Memoirs of Sir Ambrose Sherwill. Raleigh, NC: Lulu.com.

Von Aufsess, M. (1985). The von Aufsess Occupation Diary. Chichester, UK: Phillimore.

Walzer, M. (1977). Just and Unjust Wars: A Moral Argument with Historical Illustrations. New York: Basic Books.

Walzer, M. (2004). Arguing About War. New Haven, CT: Yale University Press.

Willmot, L. (2005). 'Nothing was ever the same again': public attitudes in the occupied Channel Islands June-December 1942. The Local Historian: Journal of the British Association for Local History, 35(1), 9-20. 